\title{
躰腔鏡下外科手術ロボットのための光力覚センサー
}

\section{Fiber Optic Force Sensor for Laparoscopic Surgery Robot}

\author{
佐々木 優聡（岩手大） ○学 中村 昇（岩手大） 正 島地 重幸（岩手大） \\ 正 橋元 晧 (岩手大) 正 箱崎 義英（岩手大）正萩原 義裕（岩手大）
}

Yuto Sasaki ${ }^{*}$, Noboru Nakamura ${ }^{*}$, Sigeyuki Simachi* ,Akira Hasimoto*, Yosihide Hakozaki*, Yosiyuki Hagihara* ( *: Iwate University)

\begin{abstract}
The endoscopic surgical robot system in commerce can't feed back the contact force of the tip end of the surgical instrument. As the force measurement method, overcoat method has proposed using strain gauges. By the way, electric scalpel is used as one of essential tools. The electric scalpel uses high frequency electric current and gives electric noises to the strain gauge output. This paper proposes a force sensor which has to be constructed in a thin and narrow space for the overcoat sensing and to be free from the electric noises. In the force sensor, the fiber wiring traces are devised and light from the end of an optic fiber is injected to two ends of the other optic fibers which are attached on the force-deflection part. Experiments show that the sensor has sufficient possibility as the $\mathrm{x}$ and $\mathrm{y}$ direction force sensor.
\end{abstract}

\section{1. 緒言}

腹腔鏡下外科手術は、従来の開腹手術に比べて患者に対す る負担少なくした.しかし逆に,この方法は術者に難しい術具 操作を要求することになった.術者への負担を軽減するため, マスター・スレーブ手術ロボットが考案され,かなり負担が軽 くなった。しかし未だに, 手術器具先端にかかる力の测定方法 が無く,それを術者に伝えられない問題点が残された. その力 を測定する方法として外套法が提案された。外套法では、術具 シャフトと外套管の閒のセンサー変形部に歪ゲージを貼り付 けることで, 先端部にかかる力を測定する.

ところで, 電気メスは, 生体に $300 \mathrm{kHZ} \sim 5 \mathrm{MHZ}$ の高周波電流 を流して生体を切開あるいは凝固する手術器[1]で, 外科手術 で広く用いられている.上述の外套法においては力覚センサ 一に歪センサーを使用しているため, 電気メスの電気ノイズ は, 力測定の障害となる.

本研究は電気ノイズの影響を受けない光量変化による力覚 センサーを考案し, それを外套法力覚センサーシステムに組 み込むことを目的とする。

\section{2. 基礎実験}

\section{1 実験方法}

センサーに光ファイバーを用いることとし, 先ず, 光ファイ バーの位置と出力の関係を知るために基礎実験を行った.こ の実験では, 光ファイバーを切断し, 入射側ファイバーを固定, 受光側ファイバーの位置をXY ステージにより $\mu \mathrm{m}$ 単位で変位 させた際の電圧の変化を測定した。

\section{2 光モジュール}

本研究では, 外径 $0.25 \mathrm{~mm}$ のプラスチック製光ファイバーを 用いた. 光を入射させるためのモジュールは出力く $3 \mathrm{~mW}$, 波長 $650 \mathrm{~nm}$ の赤色レーザダイオード(LD)を使用した. 光センサーに 必要とされる忘答性, 感度に優れている PIN フォトダイオー ドを受光側モジュールとして使用した.焦点距離 $13.5 \mathrm{~mm} の レ$ ンズを用いて集光した。

\section{3 結果}

基礎実験の結果より,ファイバーの間隔 X が 0,0.1 mmの時, ファイバーのずれ Y の值が正負ともに $50 \sim 200 \mu \mathrm{m}$ の範囲で計 測に使用が可能と思われる比例関係がみられた。

\section{3. カ覚センサー}

\section{1 光ファイバー測定原理}

基礎実験の結果より,図 1 に示すように, 入射側光ファイバ
ー1 本に対し,ファイバーの半径 $125 \mu \mathrm{m}$ だけずらした 2 本の 受光側光ファイバーにより変形量を測定することとした.

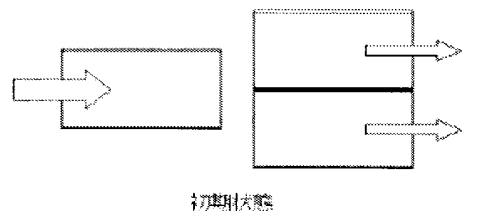

Fig.1 Measurement principle of sensor

\section{2 センサー変形部の設計}

本研究では鉗子先端部分にかかる力として $10 \mathrm{~N}$ を想定する こととした. 力覚センサーの変形部の形状は, X, Y の 2 方向の 力が測定でき，しかも既存のセンサーシステムの形状・寸法に 合わせる必要があり,図 2 に示す形状としてその概要が与え られている。

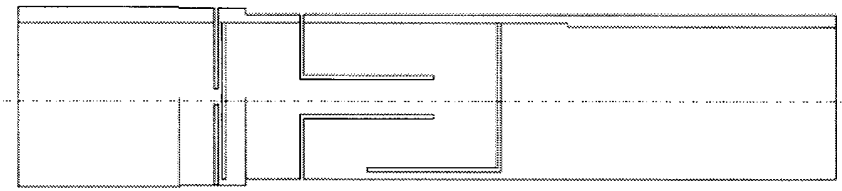

Fig.2 Summary of force sensor transformation

この変形部の内径は $9 \mathrm{~mm}$, その外径は $11.5 \mathrm{~mm}$ である.内径部 分には術具シャフトが通る内管（内径 $8.6 \mathrm{~mm}$, 外径 $9 \mathrm{~mm}$ ) が取 り付き, 外径部には外套管（内径は $11.5 \mathrm{~mm}$, 外径 $12 \mathrm{~mm}$ ）が取 り付く構造となっている.センサ一変形部全体としての肉厚 は $1.25 \mathrm{~mm}$ である必要がある。

このスペースに納まり,変形部では $10 \mathrm{~N}$ に対して $0.1 \mathrm{~mm}$ の たわみが起きる, 図 3 に示すように, 厚さ $b=0.5 \mathrm{~mm}$, 幅 $\mathrm{h}=2.2 \mathrm{~mm}$, 長さ $1=10 \mathrm{~mm}$ の両端支持はりを持つ構造とした。

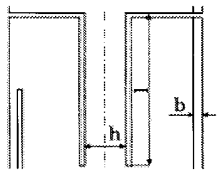

Fig. 3 Details of sensor dimensions

\section{3 光ファイバーの配置}

(X 方向センサー)センサーに光ファイバーを配置する方法と

して変形部分に対して $90^{\circ}$ の位置に光ファイバーを接着剤で 固定した。 
(Y 方向センサ一) 図 4 に示すように, Y 方向センサーの部分に おいては, ファイバー取り付位置であるスリットからばね 部までの距離は $4 \mathrm{~mm}$ しかない. そこに垂直にファイバーを配 置する場合, ファイバーの最小曲げ半径である $5 \mathrm{~mm}$ 以下に曲 げねばならず, 損失が大きくなり, 測定自体が不可能となる. そこで曲げ半径を小さくせずに, スリット部分にファイバー を配置する方法として, スリットに対して垂直ではなく, $45^{\circ}$ 傾けるという方法を採用した。

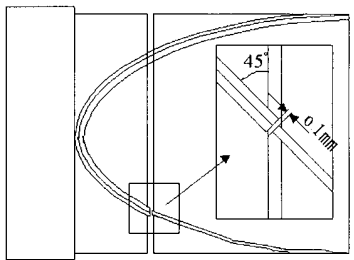

Fig.4 Y direction sensor

\section{4 実験}

内管に取り付けたセンサー変形部の外観を図 5 に示す。

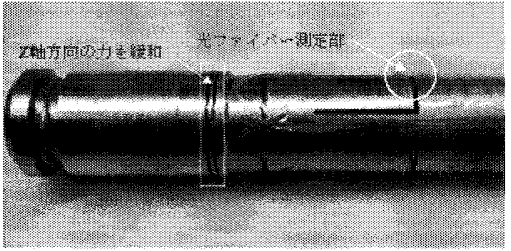

Fig.5 Sensor appearance

変形部をカバーするように外套管をかぶせることになるが， 本実験では, 同図左端の平坦部を外套管に接着剂あるいは半 田で固定する予定であるが, 一度固定すると取り外しが難し く, 取り外しの際に与える熱の影響で光ファイバーが使用不 可となってしまうことになる.そこで, 外套管の代わりとなる センサーの固定部を持つ, 図 6 に示すような実験器具を製作 した.図 7 に, X, Y 方向への負荷の様子を示す.

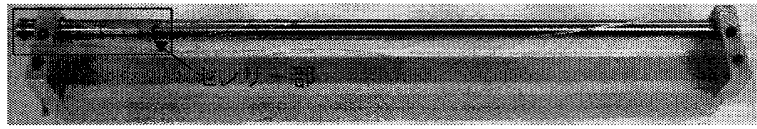

Fig.6 Appearance of experimental instrument

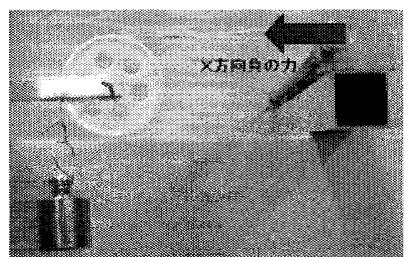

(a) Loading to direction $X$

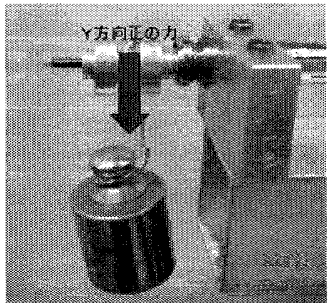

(b)Loading to direction $\mathrm{Y}$
Fig. 7 Method of loading

\section{4 実験結果}

実験で得られた結果を図 8,9 に示す.

Fig. 8(a)に見られるようにXセンサーにおけるXの正, およ びFig. 9(b)に見られるようにY方向の正負の力执よびY セン サーのY方向負の力はある程度の結果が得られた。

しかし、Fig.9(a)に見られるようにY センサーにおけるX 方向の力に対しては思わぬ結果となってしまった。これは Y センサーの光ファイバーをスリットに対して $45^{\circ}$ 傾けたこと により,センサーの曲面に光ファイバーを貼り付けることに なり, 測定部での入射側と受光側の光ファイバーの軸心がず れてしまったからではないかと考えられる.

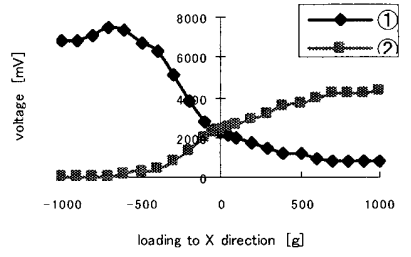

(a) Relation between $\mathrm{X}$ direction loading and voltage

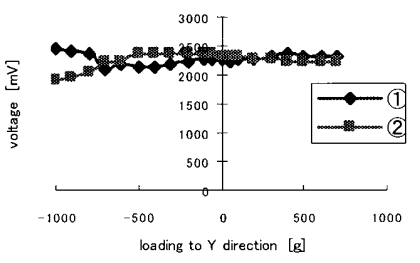

(b) Relation between $\mathrm{Y}$ direction loading and voltage Figure. $8 \mathrm{X}$ direction sensor

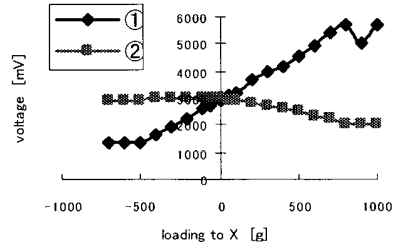

(a) Relation between $\mathrm{X}$ direction loading and voltage

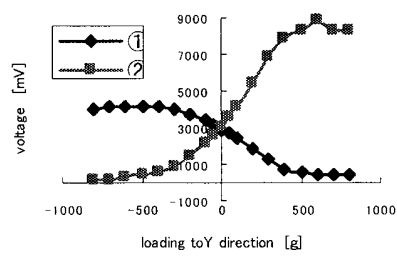

(b) Relation between Y direction loading and voltage

Fig.9 Y direction sensor

\section{4. 結言}

薄くて狭いスペースの中で光ファイバー断端のずれによる 光量変化を利用して電気ノイズの影響を受けないX, Y の 2 方 向の感度を待つ力覚センサーを試作し, 性能を調べた. その結 果，1）切断した光ファイバー間の距離が小さいとき,ずれと 電圧の関係には比例関係が見られ, $45^{\circ}$ ずらすことにより光 の入射量を増大させることが可能であることがわかった.2) 取り付けにおいては $0.5 \mathrm{~mm}$ のペースが存在すれば, 光ファ イバーを接着剤によって配置することが可能であり,センサ 一を作成するための設計值が得られた. 今回の試作では Y 方 向で設計から少しはずれた結果しか得られなかったがこれら については,ファイバー配置の際の接着や精度を高めること が今後の課題である.

\section{5. 参考文献}

[1]木村雄治, 医用工学入門, コロナ社 (1997) 